\title{
Prize Awards of the Paris Academy of Sciences
}

$\mathrm{A}^{\mathrm{T}}$ the annual public meeting of the Academy of Sciences, held on December 11, the prizes and grants awarded in 1933 were announced as follows: Mathematics.-The Francœur prize to Paul Mentré for his work on geometry.

Mechanics.-A Montyon prize to René Thiry, for his work on the mechanics of fluids ; the Poncelet prize to Eugène Bertrand de Fontviolant, for his works on mechanics; the Boileau prize to Adrien Foch, for his works on hydraulics; the PiersonPerrin prize to Paul Langevin, for his work on the mechanical applications of piezo-electric quartz.

Astronomy.-The Lalande prize to Georges Prévost for his tables of spherical functions and their integrals; the Benjamin Valz prize to Henri Labrouste for his methods of research on periods in solar phenomena; the G. de Pontécoulant prize to David Belorizky, for his work in celestial mechanics; the Antoinette Janssen foundation to Daniel Chalonge for his studies in astronomical physics.

Geography.-The Gay prize to Alphonse Berget, for his treatise on oceanography; the Alexandre Givry prize to the late Pierre Gerson, for his hydrographic work.

Navigation.-The Prix de la Marine between Gaston Dollé and Henri Dutilleul (4,000 francs) for their work on autogenous electric welding and Jean Fieux (2,000 francs) for his applications of the gyroscope to navigation; the Plumey prize between André Grebel (1,500 franes) for his study of combustion in internal combustion motors, the late Paul Leroux (1,500 francs) for his experiments in hydraulics, and Gérard Delanghe (1,000 franes) for his work on Diesel motors.

Physics.-The Gaston Planté prize to Lucien Jumau, for the whole of his work on accumulators; the Hébert prize to Pierre Fleury, for his work on photometric standards; the Henri de Parville prize to Louis Leprince-Ringuet, for his work on atomic physics ; the Hughes prize to Salomon Rosenblum, for his work on the $\alpha$-rays; the Paul Marguerite de la Charlonie prize to Amédée Guillet, for the whole of his scientific work.

Chemistry.-The Montyon prize (Unhealthy Trades) to Georges Darzens, for his work in connexion with the control of petrol storage; Paul Émile Thomas receives an honourable mention for his researches on carbon monoxide and nitrous vapours; the Jecker prize between Mme. Pauline Ramart-Lucas (5,000 francs), for her studies on the relations between the properties of molecules and their absorption spectra, Émile André (2,500 francs), for his studies on fats, and Raymond Delaby (2,500 francs), for the whole of his work in organic chemistry; the Cahours prize to Georges Allard, for his work on the electronic structure of the ethylene carbon atom and on metallic borides; the Berthelot prize to Henri Moureu, for the whole of his synthetic work in organic chemistry; the Houzeau prize to Paul Laffitte, for his studies on explosives.

Mineralogy and Geology.-The Cuvier prize to Jules Lambert, for the whole of his work on the Echinidx; the Delesse prize to Christopher Gaudefroy, for his work in physical crystallography; the Victor Raulin prize to Jean Cuvillier, for his work on the Egyptian Nummulitic; the Joseph Labbé prize to Pierre Despujols, for his studies on the mineral resources of Morocco.
Botany.-The Desmazières prize to René Vandendries, for his work on the sexuality of the Basidiomycetes; the Montagne prize to Roger Heim, for his work in mycology; the de Coincy prize to Louis Emberger, for the whole of his work.

Rural Economy.-The Bigot de Morogues prize to Serge Winogradsky, for the whole of his work on the microbiology of the soil.

Anatomy and Zoology. - The Da Gama Machado prize to Jean Verne, for his memoirs on pigments in living beings : the Savigny prize to Georges Sénevet, for his work on the blood sucking arthropods of Algeria and the Mediterranean basin.

Medicine and Surgery.-Montyon prizes to Charles Cot (2,500 franes), for his work on asphyxia, Paul Durand $(2,500$ francs), for his researches on pustular fever, Jean Lereboullet (2,500 francs), for his memoir on the tumours of the fourth ventricle; honourable mentions ( 1,500 francs) to J. A. Lièvre, for his book on parathyroidal osteosis, Adolphe Zimmern and J. A. Chavany, for their book on electro-radiological diagnosis and therapeutics of diseases of the nervous system, Henri Velu, for his book on "Dermes"; a citation to Nguyên-Van-Khai, for his memoir on the study of the prophylaxy of cholera by anticholera vaccination; the Barbier prize to Augustin Boutaric, for his researches on the properties of colloids and their relations with various biological phenomena; the Bréant prize to Georges Le Dentu, Adolphe Sicé and Marcel Vaucel, for their work on the therapeutics of human trypanosomiasis; the Godard prize to Henry Blanc, for his book on the phenolsulphonephthalein test in urinary surgery ; the Mège prize to Edgard Zunz for his book on the elements of general pharmacodynamy; the Bellion prize to Mme. Lucie Randoin, for her work on vitamins ; the Baron Larrey prize to Félix Pasteur, for his work on the utilisation of sunlight in the Sahara for the heating and purification of water.

Physiology.-The Montyon prize to Jean Gautrelet, for his book on the elements of physiological technique; the Pourat prize to Jean Chaze, for his biological work on the tobacco alkaloids; the Philipeaux prize to Pierre Dussumier de Fonbrune, for his memoir on a new micromanipulator and arrangement for the manufacture of micro-instruments; the Fanny Emden prize between Herbert $H$. Jasper (2,000 francs), for his psychological and physiological study of right and left handedness and ambidexterity, and Mme. Andrée Courtois-Drilhon, for her book on biochemical studies on the meta. morphosis of the Lepidoptera.

Statistics.-The Montyon prize to Charles Marie, for his work in connexion with the annual tables of constants and numerical data of chemistry, physics, biology and technology.

History and Philosophy of Science.-The Binoux prize to Louis Pasteur-Vallery-Radot, for his work in connexion with the publication of the "Euvres de Pasteur".

Works of Science.-The Henri de Parville prize to Gustave Juvet for his book on the structure of the new physical theories.

Medals.-Berthelot medals were awarded to Georges Darzens, Mme. Pauline Ramart-Lucas, Raymond Delaby, Henri Moureu and Paul Laffitte.

General Prizes.-The Grand prize of the physical sciences to Clodomir Houard, for the whole of his 
work ; the Bordin prize to Szolem Mandelbrojt, for his memoir on the unicity of Fourier's series ; the Lallemand prize to Alexandre Monnier, for his work on the physico-chemical mechanism of nerve action; the Petit d'Ormoy prize (Mathematical Sciences) to Arnaud Denjoy, for the whole of his mathematical work and in natural science to Louis Léger, for the whole of his work on theoretical and applied zoology ; the Estrade-Delcros prize to Emest Vessiot, for the whole of his scientific work; the Le Conte prize to Eugène Bataillon, for his work on experimental parthenogenesis; the Parkin prize to René Hazard, for his work on the pharmacology of the alkaloids; the Saintour prize to Georges Giraud, for his work on partial differential equations and integral equations ; the Lonchampt prize to Edmond Voisenet, for his work on the production of bitterness in wine and on the Adamkiewicz reaction; the Wilde prize to Mme. Irène Joliot-Curie and Frédéric Joliot, for their experimental work establishing the existence of neutrons; the Gustave Roux prize to Maurice Collignon, for his palæontological work on the Madagascan fauna; the Charles Dupin prize to Bertrand Gambier, for his work on geometry; the Marquet prize to Alexandre Bigot, for his work on the geology of Normandy.

Special Foundations.-The Lannelongue foundation to Mmes. Gabriel Cusco and Raphaël Rück.

Prizes of the Grandes Ecoles.-The Laplace prize to Maurice Allais; the L. E. Rivot prize to Maurice Allais, Raymond Fischesser, Robert Paoli and Max Dumas.

Funds for Scientific Researches.-The Gegner foundation to Valerian Agafonoff, for his researches on French soils; the Hirn foundation to Paul Ditisheim, for his work on chronometry ; the Henri Becquerel foundation to Ludovic Driencourt, for his work on navigation and geographical maps.

\section{Lovtreuil Foundation}

1. Researches on Fixed Questions.-Jean Basset (4,000 francs), for researches on the pathogeny and immunisation in anthrax; Charles Lombard $(3,000$ francs), for experimental researches on the pathogeny of cirrhosis ; Pierre Pons (3,500 francs), for researches on wool products from central and southern France; James Basset (5,000 francs), for his studies on the influence of high pressures on physical and chemical phenomena; Jean Dufay and Daniel Chalonge (5,000 francs), for chemical and spectrographic researches on the atmosphere carried out at the Observatories at the Jungfraujoch and at Interlaken; André Charriou, for his researches on the latent photographic image; Paul Henri Fleuret, for his studies of the mechanism of the formation of ketonic and oxalic acids; Laboratoire central d'electricité $(12,000$ francs $)$, for making the standard of inductance with a view to the measurement in absolute value of the unit of electrical resistance; Charles Marie (3,000 francs), for systematic researches in electrochemistry; Henry Pollet (2,000 francs), for his studies of atmospheric electricity during dust winds in north China.

2. Researches to be carried out in the French Colonies.-Henri Humbert (15,000 franes), as a contribution to the cost of an expedition to Madagascar and southern Africa with a view to the study of various types of vegetation and their variations under the influence of the nature of the soil, altitude and climate; Louis Dubertret (7,000 francs), as a contribution to an exploration of the volcanic desert region to the south-east of Damascus; Jean Piveteau (4,500 francs), to contribute to the cost of excavations in a deposit of vertebrates at Oranais.

3. Purchase of Laboratory Material.-Ecole nationale vétérinaire de Lyon (6,000 francs), for the purchase of a Phillips' portable apparatus for radiography and radioscopy ; Léon Huillet (3,000 franes), for the purchase of a Chevenard temperature regu. lator ; Jules Lemoine (2,000 francs), for the purchase of a microphone designed for the study of internal friction in metals; Henri Chaumat $(2,000$ franes $)$ for the purchase of material for the construction of an electrostatic machine; Maurice Javillier $\mathbf{3 , 0 0 0}$ francs), for the purchase of an incubator ; Raymond Ricard (3,000 francs), for the purchase of a Fabry and Pérot interference standard.

4. Libraries.-The following grants are given to libraries for the purchase of books : Ecole polytechnique (7,000 francs), Ecole national vétérinaire d'Alfort (10,000 francs), Ecole national vétérinaire de Toulouse (2,000 francs), Ecole supériore de Chimie de Mulhouse (2,000 francs), Société française des Electriciens (1,500 francs), for the purchase of "Faraday's Diary".

Publications.-Archives de zoologie expérimentale (10,000 franes), for assisting the publication of a jubilee volume; Bibliothèque national et universitaire de Strasbourg (5,000 francs), as a contribution to the publication of the catalogue of scientific periodicals; Emile Mathias (4,000 franes), for the publication of two memoirs dealing with the action of lightning on man and animals.

\section{Mme. Victor Noury Foundation}

Norbert Casteret (2,000 francs), for his hydrological and speleological explorations in the Pyrenees ; Mlle. Madeleine Friant (2,000 francs), for her book on the dentition of mammals ; Josué Hoffet $(2,000$ francs), for his study of the centre of Indo-China and his ethnological work in Annam; Nicolas Menchikoff $(2,000$ francs $)$, for his numerous expeditions in the Sahara and the Libyan desert with resulting contributions to geology ; Edouard Fischer $(1,500$ francs), for his researches on the marine fauna of the Channel.

\section{Other foundations}

Pierre Lafitte Foundation to René Mesny (3,000 francs), for the whole of his work on radio-electricity. The Roy-Vaucouloux Foundation to Philippe Lasseur, for his work in the laboratory of microbiology at Nancy. The Charles Frémont Foundation to Léon Pomey (2,500 francs), for his work on geology and analysis.

\section{University and Educational Intelligence}

CAMBRIDGE.-A lecture on the Liversidge Foundation will be delivered by Prof. R. H. Fowler in the Lecture Theatre of the Engineering Laboratory on Friday, February 2, at 5 p.m. The subject of Prof. Fowler's lecture will be "Heavy Hydrogen".

A LIBERAL education as a prophylactic against the manifold ills that threaten the very existence of western civilisation is the theme of an address 